\title{
Profitability of Improved Seed Adoption on Small Holders Maize Farmers in Abuja Nigeria
}

\author{
Ndem Chijioke ${ }^{1} \&$ Uteh Akaninyene $^{1}$ \\ ${ }^{1}$ National Agricultural Seed Council Abuja, Nigeria \\ Correspondence: Ndem Chijioke, National Agricultural Seed Council Abuja, Nigeria.
}

Received: September 3, 2018

Accepted: December 31, 2018

Online Published: January 2, 2019

doi:10.11114/bms.v4i4.3922

URL: https://doi.org/10.11114/bms.v4i4.3922

\begin{abstract}
The study analysed the profitability of improved seed adoption on the profitability and technical efficiency of smallholder maize farmers in Abuja, Nigeria. Descriptive statistics were used to describe the socioeconomic characteristics, gross margin analysis was used to determine the costs and returns of maize production. The t-test was used to compare the yield of improved maize seed adopters and non-adopters. The logit regression was used to analyse the determinants of adoption. The stochastic production frontier model was used to determine the technical efficiency of IMV. The results revealed that the average age of respondents (adopters and non-adopters) was 48 years and 39 years, respectively. Furthermore, $56 \%$ and $66 \%$ were male, $75 \%$ and $93 \%$ were married with average household size of 6 and 7 persons, respectively, and majority had formal education. Adopters had a mean farm size of 1.95 ha, while non-adopters had a mean farm size of 1.76 ha. The gross margin analysis result showed the profitability index for IMV and local seed were 0.66 and 0.41 , respectively. The t-test result showed that IMV had higher yield per hectare $(2,713.66 \mathrm{~kg} / \mathrm{ha})$ compared to local maize variety $(1,281.33 \mathrm{~kg} / \mathrm{ha})$. The result of maximum likelihood estimate showed that the mean technical efficiency was 0.56 and 0.49 for adopters and non-adopters, respectively. The study revealed that adopters of improved maize seed varieties earned higher profits and were more technically efficient than non-adopters. It recommended the strengthening of extension services to enhance adoption through awareness by government. Farmers should form cooperatives to enable resourceful negotiation for inputs. Also, an improvement in the research and development of high quality improved maize varieties should be encouraged.
\end{abstract}

Keywords: profitability, improved seed, adoption, maize

\section{Introduction}

Maize (Zea mays, L.) is one of the main cereal crops of West Africa. It is the fourth most consumed cereal during the past two decades, after sorghum, millet and rice in Nigeria (Food and Agriculture Organization Statistics, 2012). Nigeria is the $11^{\text {th }}$ largest producer of maize in the world, and the $2^{\text {nd }}$ largest maize producer in Africa after South Africa (FAO Statistics, 2012). As a versatile crop that is not just consumed domestically, maize is used industrially by flour millers, brewers, bakers of bread and confectionery and animal feed manufacturers.

Maize is becoming a miracle seed of Nigeria's agricultural and economic development. It has established itself as a very significant component of the farming system and determines the cropping pattern of the predominantly poor farmers, especially in the northern states in Nigeria (Ahmed, 1996). Maize is well-known as one of major cereal crops grown and consumed across all agro ecological zones of Nigeria. It has attained the highest growth rate of the major crops since the 1970s (Kamara, Kureh, Menkir, Kartung, Tarfa, and Amaza, 2006). The introduction of hybrid varieties resulted in accelerated growth in the mid-1990s, following the injection of extra-early varieties (Abate, Onyibe, Ado, Fajemasin, Menkir, Abdoulaye, and Badu-Apraku, 2014).

Oyelade and Anwanane (2013) noted that maize is a cereal crop with the highest yield potential with an annual growth rate of $4.2 \%$ compared to $2.3 \%$ and $1.9 \%$ for sorghum and millet, respectively. It is important for the nourishment of both man and animals. Maize currently occupies the largest area of land cultivated followed by sorghum, cassava, millet, cowpea, yam, rice and groundnut (NBS, 2012). About $70 \%$ of the maize producers are small-scale farmers, cultivating between 0.5-2.0 hectares with low technology (Oyelade and Anwanane, 2013).

Seeds are basic agricultural input. Palmer (2005) noted that quality seeds of any preferred varieties are the basis for improved agricultural productivity. Quality seeds respond to farmers' need to increase productivity and other crop uses. 
The use of improved quality crop cultivars for profitable farming experienced by farmers has been recognized as the most important strategy in boosting agricultural production and accelerating achievement of National Food Security Programme (Ruma, 2008).

Improved quality seed is not only the economical and basic input of increasing yield but also fundamental in raising the efficiency of other inputs like fertilizers and agro-chemicals (Shobowale, 1994). Improved maize variety (IMV) has the capacity to improve yield, income and productivity of farmers. In essence, no agricultural practice for instance fertilizer application and irrigation can improve crop production beyond the limit set by seed (Alliance for a Greener Revolution in Africa (AGRA) and National Agricultural Seed Council (NASC), 2008).

Objectives of the Study:

This paper aims at looking into the key factors propelling economic benefits of improved maize seed production in FCT, Abuja, Nigeria. The objective of the study, therefore are to:

1. Examine the factors affecting the production of improved maize seeds in FCT, Abuja

2. Propose management measures to know the difference between the yield of improved maize seed adopters and non-adopters?

3. Identifying and analysing the costs and returns of improved maize seed adopters compared with non-adopters?

\section{Review of Literature}

Maize is the most important cereal food crop in sub-Saharan Africa (SSA) with more than $50 \%$ of all countries assigning over $50 \%$ of their cereal crop production area to maize. Over 650 million people in SSA consume on average $43 \mathrm{~kg}$ of maize/year (FAOSTAT, 2006). In Nigeria, for instance, maize is one of the two major crops that occupy about $40 \%$ of the land area under agricultural production, and accounts for about $43 \%$ of the maize grown in West Africa (Smith, Weber, Manyong and Fakorede 1997; Phillip, 2001). The total land area planted by small scale maize farmers in West and Central Africa increased from 3.2 million in 1961 to 8.9 million in 2005 (FAO, 2005).

Maize is high yielding, easy to process, readily digested, and cheaper than other cereals. It is also a versatile crop growing across a range of agro-ecological zones. Every part of the maize plant has economic value: the grain, leaves, stalk, tassel, and cob can all be used to produce a large variety of food and non-food products. According to IITA (2001) report, maize contains 80 per cent carbohydrate, 10 per cent protein, 3.5 per cent fiber and 2 per cent mineral. Iron and Vitamin B are also present in maize. Among different income groups, maize is a relatively more important source of both calories and protein for the poorer proportion of consumers, including HIV/AIDS affected families, who cannot afford more expensive foods, such as bread, milk or meat (Byerlee and Heisey, 1997). Maize production, therefore, is of strategic importance for food security and the socioeconomic stability of the country.

In industrialized countries, maize is largely used as livestock feed and as a raw material for industrial products, while in low-income countries, it is mainly used for human consumption (IITA, 2001). Although maize is increasingly being utilized for livestock feed, it is still a very important staple food for millions of Nigerians. Maize alone contributes about $80 \%$ of poultry feed and this has a great implication for protein intake in Nigeria (FAO, 2008). Maize is therefore, considered a very vital food crop to the economic growth of the nation through its contribution to food security and poverty alleviation. In order to satisfy specific consumer preferences, the varieties developed are varied in grain colour (mainly white and yellow) and endosperm characteristics (dent, flint, floury and varying grades between the three). Flint maize is relished as green maize whereas the dent varieties have starch content preferably with minimal chaff and therefore suitable for food dishes such as Ogi and Tuwo.

\section{Methods}

Database and Sample Size:

Multi-stage random sampling technique was employed to select a target sample of 300 maize farmers for the study. There are six (6) Area Councils in the FCT namely; Abaji, Kuje, Gwagwalada, Kwali, Bwari and the FCT Municipal. In the first stage, four (4) Area Councils; Bwari, Gwagwalada, Kuje and Kwali were selected purposively based on the preponderance of maize farmers in these Area Councils. The second stage of the procedure involved purposive selection of five maize producing villages from each of the selected Area Councils. The third stage involved a simple random selection of equal number of improved maize seed adopters and non-adopters from each of the selected villages. The formula used in selecting sample size proportionate to the population of maize farmers in each Area Council is Steven's (1993) formula expressed as:

$$
n h=\frac{n \cdot N h}{N}
$$


Where: $\mathrm{nh}=$ sample size that was determined, $\mathrm{n}=$ targeted number of respondents $(\mathrm{n}=300)$,

$\mathrm{Nh}=$ sampling frame (total number of farming households in each Area Council),

$\mathrm{N}=$ finite population (total population of farming households in the study area).

Table 1 presents the total number of maize farmers from the selected Area Councils used for the study. Applying the formula in equation 8, sample size of $62,100,66$ and 72 respondents were selected and interviewed in Bwari, Gwagwalada, Kuje, and Kwali Area Councils, respectively.

Table 1. Number of maize farmers in selected Area Councils

\begin{tabular}{lll}
\hline Area Councils & Sampling Frame & Sample Size \\
\hline Bwari & 1965 & 62 \\
Gwagwalada & 2975 & 100 \\
Kuje & 2115 & 66 \\
Kwali & 2335 & 72 \\
Total & 9390 & 300 \\
\hline
\end{tabular}

Source: Agricultural Development Programme (ADP) Office, FCT (2015)

Method of Data Collection:

The study used primary data. Data were collected on socio-economic characteristics of the respondents such as age, gender, marital status, household size, educational status, extension contact, farming experience, farming status, labour source and income. Production information collected include farm size, land, labour, fertilizer and yields. Also, information on variety of IMV, sources of IMV, awareness and duration of awareness were collected. Farmers that adopted improved maize varieties were able to identify these varieties used by the names attached on the package. The respondents interviewed were able to identify the type of Four enumerators were engaged to administer the questionnaire by personal interview. The period of data collection was August-November, 2015.

Analytical Techniques:

The following were the various analytical tools that were used to achieve the objectives stated for this study: descriptive statistics, gross margin analysis, stochastic production frontier and multinomial logit regression.

\section{Results}

4.1 Examine the Factors Affecting the Production of Improved Maize Seeds in FCT, Abuja-Determinants of Adoption of Improved Maize Varieties (Imvs)

The binary logit regression was used to obtain the determinants of adoption of IMV by regressing adoption against farmer specific characteristics such as age, level of formal education, non-farm income, household size, farm income, farming experience and institutional factors such as extension contact and farm size. The results presented in Table 4.6 shows that the coefficient of age (0.098), educational status (0.120), non-farm income (-7.99e-06), household size $(-0.376)$, farm income $(6.47 \mathrm{e}-06)$ and labour $(0.049)$ were statistically significant at $1 \%$ probability level. Extension contact $(0.227)$ and farm size $(-0.602)$ were statistically significant at $5 \%$ while farming experience $(-0.037)$ was significant at $10 \%$ level of probability.

Coefficient of age (0.098) had a positive sign which indicates that the level to which a maize farmer adopts improved seed increases with age. Age of farmer is often linked with experience and ability to improvise techniques. As a farmer advances in age, his ability to identify specific challenges affecting his enterprise develops. Adesina and Baidu-Forson (1995) argued that older farmers have more experience in crop production and exposure to the potentials in modern technology than younger farmers. However, Cavane and Subedi (2009) asserted that age is one of the human resources that has been frequently associated with non-adoption of IMV among smallholder farmers in developing countries.

The positive sign of educational status shows that adoption level increases as farmers acquire formal education. Farmer's ability to accept improved technology will likely prevail where there is greater access to formal education at all levels. This implies that increased formal education could lead to increased technical efficiency for the farmers. Education might be regarded as a factor for increased efficiency among farmers (Dimelu, Okoye, Okoye, Agwu, Aniedu and Akinpela, 2009; Simonyan, 2010). Similarly, Awe (1999) observed that literacy level influence farmers' ability to adopt improved technology in south west Nigeria. 
Non-farm income had a positive sign and was statistically significant at $5 \%$ level of probability. This implies that as non-farm income increases, farmers still adopt and continue to use improved maize varieties because of the additional income at their disposal and due to the accrued benefits attached to planting these improved varieties which could lead to increased productivity. Coefficient of household size had negative sign and was statistically significant at $1 \%$ probability level. This implies that as household size increases, level of adoption diminishes. This is in line with the finding of Bamire, Fabiyi and Manyong, (2002) that family size has been recognized to play a vital role in the adoption of any technology or farm practice. This may well be attributed to the cost of acquiring new farm technology where a farmer's focus is household survival. Other factors could be accessibility and usage of improved technology.

Coefficient of farming experience had negative sign and significant at $10 \%$. This indicates that an increase in the variable will result in less adoption of improved maize variety. This is against the expectation that farming experience leads to better understanding and utilization of improved technologies (Zanu, Antwiwaa and Agyemang, 2012). It is also expected that experienced farmers may be able to understand the nature of risk associated with each of the technologies, having adopted or seen some of them used over time

\subsection{Propose Management Measures to Know the Difference Between the Yield of Improved Maize Seed Adopters and Non-Adopters}

T-test was used to compare the yield of improved maize seed adopters and non-adopters in the study area. The results showed an average of $2,713.66 \mathrm{~kg} / \mathrm{ha}$ and $1,281.33 \mathrm{~kg} / \mathrm{ha}$ for adopters and non-adopters, respectively. This indicates that the yield of IMV was more than two times the yield of local variety in the study area, with standard deviation of 6.13E-09. This finding is in line with apriori expectation that there is a significant difference between the yield of IMV and local variety.

Test of hypothesis of the study:

The null hypothesis $\left(\mathrm{H}_{0}\right)$ which states that there is no significant difference in the maize yields of adopters and non-adopters of improved seeds was tested using a t-test and the result presented in table 2 . The calculated $t$-value was 6.8 and exceeds the critical value of 1.96 , therefore the $\left(\mathrm{H}_{0}\right)$ is rejected at $5 \%$ level of probability. The result indicates that adopting improved maize seed varieties is more profitable than local varieties.

Table 2. T-test for yield of adopters and non-adopters

\begin{tabular}{lcc}
\hline Variables & Adopters & Non-adopters \\
\hline Yield & 2713.66 & 1281.33 \\
Variance & 8010936.13 & 951259.9553 \\
Observations & 150 & \\
Pooled Variance & 4481098.043 & \\
Hypothesized Mean Difference & 0 & \\
Df & 298 & \\
t Stat & -5.859796144 & \\
P $(\mathrm{T}<=\mathrm{t})$ one-tail & $6.13102 \mathrm{E}-09$ & \\
t Critical one- tail & 1.649982976 & \\
P $(T<=t)$ two-tail & $1.2262 \mathrm{E}-08$ \\
T Critical two-tailed & $1.967956506^{* * *}$ & \\
T Calculated & 6.8 &
\end{tabular}

Source: Field survey (2015)

Note: $*=$ significant at $10 \%, * *=$ significant at $5 \%, * * *=$ significant at $1 \%$.

\subsection{Identifying and Analysing the Costs and Returns of Improved Maize Seed Adopters Compared With Non-Adopters}

Costs and returns of adopters and non-adopters of IMV in the study area are presented in Table 4.7. Financial analysis was carried out to ascertain the economic potentials of using both varieties of maize.

Results presented in the table show that cost of hired labour for adopters and non-adopters were $42.15 \%$ and $40.62 \%$, respectively, of the total cost, while family labour accounted for $13.20 \%$ and $26.15 \%$ for adopters and adopters, respectively. The cost of fertilizers for adopters and non-adopters accounted for $14.52 \%$ and $7.37 \%$ respectively, while the cost of agrochemicals accounted for $4.85 \%$ and $5.33 \%$, respectively. This implies that labour, fertilizer and agrochemicals were vital inputs in maize production in the study area. This is line with the findings of Akanbi, Omotesho and Ayinde (2011) who stated that fertilizer, labour and agrochemical were parts of the most important inputs in crop production in Nigeria. It is noteworthy that adopters spent more on agrochemicals than non-adopters due to the expected returns on use of improved maize variety (Ugwumba and Omojola, 2012).

The table further reveals that the variable cost for adopters constituted $92.12 \%$ of the total cost which is lower than that of non-adopters $(95.83 \%)$. This implies that adopters spent more in their farm operation. The total revenue generated 
per hectare were 198, 711.80 and $\$ 101,841.29$ for adopters and non-adopters, respectively. The higher revenue derived from adopters is attributed to the higher yield levels of IMV per hectare compared with local varieties (Amazaet al., 2008).

Gross margin (GM) analysis was used to compare the performance and profitability of each of the two enterprise (adopters and non-adopters). Table 4.7 shows the gross margin of $\$ 136,670.53$ per hectare for adopters while $\$ 44$, 275.11 per hectare for non-adopters. This implies that adopters of improved maize seed varieties earned more profit than non-adopters in the study area. In other words, adoption of improved technology helps the farmers to generate more income from their enterprise (Amazaet al., 2008).

Table 3 shows the gross ratios of 0.339 and 0.590 for adopters and non-adopters of improved maize seed varieties, respectively. This indicates that the total costs of production is about $33 \%$ of the gross income for adopters and $59 \%$ of the gross income for non-adopters respectively. This shows that farms that adopted improved maize seeds were more financially efficient than non-adopters.

Table 3 also shows the operating ratios of 0.312 and 0.565 for adopters and non-adopters, respectively. This indicates that $31 \%$ of the gross income was used to pay for the variable costs for the adopters, while $57 \%$ of the gross income was used to pay for the variable cost for non-adopters. The operating cost is directly related to the variable input usage. The lower the value of the operating ratio, the better the financial position of the farm. An operating ratio of one means that the gross income scarcely covers the expenses on the variable inputs used on the farm. It can be deduced from the result that maize farmers should be encouraged to use improved maize seeds for their farm operation.

The return on capital invested in Table 3 shows $1.95 \%$ and $0.70 \%$ for adopters and non-adopters respectively. This implies that for every $\$ 1$ invested by adopters and non-adopters, 95kobo and 70kobo was realized as profit, respectively. The result shows that using improved maize seed varieties was more profitable than using local varieties in the study area.

Table 3. Costs and returns analysis in maize production

\begin{tabular}{|c|c|c|c|c|c|}
\hline & \multirow[t]{2}{*}{ Cost of items } & \multicolumn{2}{|l|}{ Adopters } & \multicolumn{2}{|c|}{ Non Adopters } \\
\hline & & $\begin{array}{l}\text { Amount } \\
\text { (N/ha) }\end{array}$ & $\%$ & $\begin{array}{l}\text { Amount } \\
\text { (N/ha) }\end{array}$ & $\%$ \\
\hline \multirow[t]{12}{*}{$\mathbf{A}$} & Variable & & & & \\
\hline & Cost of seeds & 3018.96 & 4.48 & - & - \\
\hline & Family labour & 8887.96 & 13.20 & 15707.41 & 26.15 \\
\hline & Hired labour & 28385.40 & 42.15 & 24401.09 & 40.62 \\
\hline & Cost of agrochemicals & 3265.34 & 4.85 & 3202.14 & 5.33 \\
\hline & Cost of fertilizer & 9777.63 & 14.52 & 4427.79 & 7.37 \\
\hline & Consultancy services & 44.34 & 0.07 & 3.76 & 0.01 \\
\hline & Salaries of staff & 590.04 & 0.88 & 94.02 & 0.16 \\
\hline & Cost of repairs & 311.08 & 0.46 & 271.12 & 0.45 \\
\hline & Transportation & 4454.98 & 6.61 & 5169.24 & 8.61 \\
\hline & Loading and offloading cost & 1056 & 1.57 & 680.73 & 1.13 \\
\hline & Processing and preservation & 2249.52 & 3.34 & 3608.86 & 6.01 \\
\hline \multirow{3}{*}{$\begin{array}{l}\text { B } \\
\text { C }\end{array}$} & Total variable costs & 62041.27 & 92.12 & 57566.18 & 95.83 \\
\hline & Fixed costs : & & & & \\
\hline & Depreciation on fixed costs & 5307.60 & 7.88 & 2504.78 & 4.17 \\
\hline D & Total costs $=(B+C)$ & 67348.87 & 100.00 & 60070.96 & 100.00 \\
\hline $\mathbf{E}$ & Total revenue $(\mathrm{GI})$ & 198711.80 & & 101841.29 & \\
\hline $\mathbf{F}$ & Net farm income $=(E-D)$ & 131362.93 & & 41770.33 & \\
\hline $\mathbf{G}$ & Farm financial ratios & & & & \\
\hline \multirow{7}{*}{$\mathbf{I}$} & Gross margin $=\mathrm{E}-\mathrm{B}$ & 136670.53 & & 44275.11 & \\
\hline & Gross ratio $=\mathrm{D} / \mathrm{E}$ & 0.339 & & 0.590 & \\
\hline & Operating ratio $=\mathrm{B} / \mathrm{E}$ & 0.312 & & 0.565 & \\
\hline & Fixed ratio $=\mathrm{C} / \mathrm{E}$ & 0.026 & & 0.024 & \\
\hline & Return on capital invested $=\mathrm{F} / \mathrm{D}$ & 1.95 & & 0.70 & \\
\hline & Income/expenses ratio $=\mathrm{E} / \mathrm{D}$ & 2.95 & & 1.70 & \\
\hline & Profitability Index $=F / E$ & 0.66 & & 0.4 & \\
\hline
\end{tabular}

Source: Field survey (2015)

The income/expenses ratio was 2.95 and 1.70 for adopters and non-adopters, respectively. This implies that the farm generated 2.95 times more income than expenses for adopters of improved maize varieties and 1.70 times more income for non-adopters. This shows that the farms that adopted IMV were more profitable than non-adopters. Larger income/expenses ratio shows the good financial standing of the enterprise. The profitability index (P.I.) was 0.66 and 0.40 for adopters and non-adopters respectively. This implies that for every naira earned as revenue, 66kobo was returned to the maize farmer that adopted improved seeds, compared to 40kobo for the non-adopters. Profit index (PI) 
shows the level of returns per income. For a farm to be profitable, the PI should be greater than zero. If PI is negative, it implies that the farm is losing money. This result shows that IMV was profitable in the study area.

\section{Conclusion}

The study concluded that improved maize seed adoption was more profitable than using local seed. Adoption of IMV was determined by socioeconomic characteristics of smallholder farmers. The stochastic frontier model showed that the determinants of technical efficiency for adopters were age, educational status and farm income while the determinants of technical efficiency for non-adopters were educational status, farm income and capital input. The study further concluded that adopters were more technically efficient compared to non-adopters thus had higher gross income per hectare, even though there still exist a large room for improvement in the levels of efficiency. The t-test result showed that adoption of IMV gave greater yield compared to non-adoption. The constraints showed high cost of input, cost of IMV, access to IMV and unavailability of land as high ranked among adopters and non-adopters.

\section{Acknowledgement}

I acknowledge that the authors have no conflict of interest as this research was aimed at improving lives and economies.

\section{References}

Abate et al. (2014). DT Maize. A Quarterly Bulletin of the Drought Tolerant Maize for Africa Project, 3(1), 1-4.

Abdulai, A., \& Huffman, W. (2000).Structural adjustment and economic efficiency in Northern Ghana. Economic Development and Cultural Change, 48(3), 503-520. https://doi.org/10.1086/452608

Adesina, A. A., \& Baidu-Forson, J. (1995). Farmers' perception and adoption of new agricultural technology: evidence from analysis in Burkina Faso and Guinea, West Africa. Agricultural Economics, 13(1), 1-9.

https://doi.org/10.1016/0169-5150(95)01142-8

Agricultural Development Programme (ADP) (2015). Annual Report.FCT Abuja Nigeria.

Ahmed, B. (1996). Economic Analysis of Fertilizer used in maize production in the Northern Guinea Savannah of Nigeria. Unpublished Ph.D Thesis, Department of Agriculture Economics and Rural Sociology, Ahmadu Bello University, Zaria: Nigeria.

Ahmed, E. E. B., Maruod, M. E., Elkhidir, E. E., \& Mahmoud, T. E. (2013). Impact of improved seeds on small farmers' productivity, income and livelihood in Bara Locality of North Kordofan State, Sudan. American International Journal of Contemporary Research, 3(11), 75-87.

Aigner, D., Lovell, C. A. K., \& Schmidt, P. (1977). Formulation and estimation of stochastic frontier production function models. Journal of Econometrics, 6(1), 21-37. https://doi.org/10.1016/0304-4076(77)90052-5

Ajibefun, I. A. (2006). Linking socio-economic and policy variables to technical efficiency of traditional Agricultural production: Empirical evidence from Nigeria. Paper presented at International Association of Agricultural Economists' Conference, Gold Coast, Australia.

Ajibefun, I. A., Battesse, G. E., \& Daramola, A. G. (2002). Determinant of technical efficiency in smallholders' crop farming in Oyo State Nigeria.Application of frontier production function. Quarterly Journal of International Agriculture, 41(3), 226-240.

Akanbi, U. O., Omotesho, O. A., \& Ayinde, O. E. (2011). Analysis of technical efficiency of rice farms in Duku Irrigation Scheme, Kwara State, Nigeria. Nigerian Journal of Agriculture, Food and Environment, 7(3), 65-72.

Akinrinde, E. A., \& Olukotun, O. A. (2002). Principles and practices of arable crop production.Immaculate-City publishers.

Ali, M. (1996). Quantifying the socio-economic determinants of sustainable crop production: An application of wheat cultivation in the Tarui of Nepal. Agricultural Economic, 14(1), 45-60. https://doi.org/10.1016/0169-5150(95)01161-7

Amaza, P., Kwacha, A., \& Kamara, A. (2008). Farmers'perceptions, profitability, and factors influencing the adoption of improved maize varieties in the Guinea Savannah of Nigeria. International Institute of Tropical Agriculture, Ibadan, Nigeria, 1-5.

Anyanwu, S. O. (2009). Gender and resource productivity among small-scale food crop farmers in Rivers State, Nigeria. Global Approaches to Extension Practice, 5(1), 107-114.

Audu, V. I., \& Aye, G. C. (2014). The effect of improved maize technology on household welfare in Buruku, Benue State, Nigeria. Cogent Economics and Finance, 2(1), 1-10. https://doi.org/10.1080/23322039.2014.960592 
Awe, D. A. (1999). Soil fertility management using organic fertilizers and low-external-input techniques in south western Nigeria. Paper presented at a National Workshop on Soil conservation and Soil Management for Sustainable Rural Development in Nigeria, Ibadan.

Ayinde, O. E, Adewumi, M. O., Olatunji, G. B., \& Babalola, O. A. (2010). Determinants of adoption of downy mildew resistant maize by small-scale farmers in Kwara State, Nigeria. Global Journal of Science Frontier Research, 10(1), $7-12$.

Baha, M. R. (2013). Sources of technical efficiency among smallholder maize farmers in Babati District, Tanzania. International Journal of African and Asian Studies, 1(1), 34-41.

Bamire, A. S., Fabiyi, Y. L., \& Manyang, V. M. (2002). Adoption pattern of fertilizer technology among farmers in the ecological zones of south western Nigeria: A Tobit analysis. Australian Journal of Agricultural Research, 53, 901-910. https://doi.org/10.1071/AR01095

Battesse, G. E. (1992). Frontier production functions and technical efficiency: A survey of empirical applications in agricultural economics. Agricultural Economics, 7(1), 185-208. https://doi.org/10.1016/0169-5150(92)90049-5

Battesse, G. E., \& Coelli, T. J. (1995). A model for technical inefficiency effect in stochastic frontier production for panel data.Empirical Economics, 20(2), 325-345. https://doi.org/10.1007/BF01205442

Bauer, S., \& Karki, L. (2004). Technology adoption and household food security.Analysing factors determining technology adoption and impact of project intervention: A case of smallholder peasants in Nepal. Germany: Paper presented in DeutscherTropentag.

Bernard, C. H. (2003). Economic analysis of cassava-based cropping in crude oil producing area: A case study of River State Nigeria. Unpublished Ph.D Thesis, submitted to theDepartment of Agricultural Economics and Rural Sociology, Ahmadu Bello University Zaria, Nigeria. 38-41.

Binod, K. (2010). Determinants of adoption of improved maize varieties in developing countries: A Review. International Research Journal of Applied and Basic Sciences, 1(1), 1-7.

Bravo-Ureta, B., \& Pinheiro, A. (1997). Technical, economic, and allocative efficiency in peasant farming: Evidence from the Dominican Republic. The Developing Economies, 35(1), 48-67.

https://doi.org/10.1111/j.1746-1049.1997.tb01186.x

Byerlee, D., \& Heisey, P. W. (1997). Evolution of the African maize economy in Byerlee, D. and Heisey, P., West Africa's Emerging Maize Revolution, edited by D. Byerlee and C. K., Eicher. London, UK: Lynne Rienner Publishers.

Cavane, E., \& Subedi, M. (2009). Setting the stage: A note on farmers'attitudes and adoption of improved maize in Mozambique. Proceedings of the 25th Annual Meeting, Inter Continental San Juan Resort, Puerto Rico.

Coelli, T. J. (1994). A Guide to DEAP Version 2.1: A data envelopment analysis (computer) program. Department of Econometrics, University of New England Armidale, NSW, 2351, Australia.

Daniel, J. D., Sanda, A. A., \& Adebayo, E. F. (2010). Net income analysis and efficiency of resource use among cotton farmers in the Southern part of Adamawa State, Nigeria.Agriculture and Biological Journal of North America, 1(6), 1215-1222. https://doi.org/10.5251/abjna.2010.1.6.1215.1222

Debreu, G. (1951). The coefficient of resource utilization. Dans Econometrics, 273-292. https://doi.org/10.2307/1906814

Dimelu et al. (2009). Determinants of gender efficiency of small-holder cocoyam farmers in Nsukka Agriculture Zone of Enugu State. Scientific research and Essay.Academic Journals, 4(1), 28-30.

Doss, C. R. (2003). Understanding farm-level technology adoption: Lessons learned from CIMMYT's micro surveys in Eastern Africa. Centro International de Mejoramiento de Maíz y Trigo (International Maize and Wheat Improvement Centre-CIMMYT).

Dowswell, C. R., Paliwal, R. L., \& Cantrell, R. P. (1996). Maize in the third world. Oxford: Westview Press.

Ebojei, C. O., Ayinde, T. B., \& Akogwu, G. O. (2012). Socio-economic factors influencing the adoption of hybrid maize in Giwa Local Government Area of Kaduna State. The Journal of Agricultural Science, 7(1), 23-32. https://doi.org/10.4038/jas.v7i1.4064

Etim, N. A., \& Okon, S. (2013). Sources of technical efficiency among subsistence maize farmers in Uyo, Nigeria. Discourse Journal of Agriculture and Food Science, 1(4): 48-53.

Ezeh, C. I., Anyiro, C. O., \& Chukwu, J. A. (2012). Technical efficiency in poultry broiler production in Umuahia, Abia 
State, Nigeria. Greener Journal of Agricultural Science, 3(1), 33-39.

Fadere, O. A., \& Akerele, D. (2011). Factors influencing adoption decision of maize farmers in Nigeria. International Journal of Food Agricultural Economics, 2(3), 45-54.

Farrel, M. J. (1957). The measurement of productive efficiency. Journal of the Royal State of Statistics, 120(1), $253-281$. https://doi.org/10.2307/2343100

Federal Capital Territory Administration (FCTA) (2013). Retrieved from http://www.fct.gov.ng/index7732.htmloption=com_content\&view=article\&id=45\&Itemid=87 on 2nd of March, 2014.

Food and Agriculture Organisation (2005). Retrieved from http://www.fao.org/es/ESD/AT2050web.pdf on 18th of November, 2015.

Food and Agriculture Organisation (2006). Retrieved from http://www.fao.org/es/ESD/AT2050web.pdf on 20th of January, 2015.

Food and Agriculture Organization (F.A.O.) (2008). FAO Global information and early warning system on food and agriculture. World Food Programme (GIEWS), Special Report on markets, prices and food situations for Benin, Niger and Nigeria.

Food and Agriculture Organization Statistics (2012). Retrieved from http://faostat.fao.org/site/291/default.aspx on 24th of November, 2014.

Fried, H., Lovell, K., \& Schmidt, S. (2008). The measurement of productive efficiency and productivity growth. New York: Oxford University Press. 23. https://doi.org/10.1093/acprof:oso/9780195183528.001.0001

Geofrey, O. (2011). Improved input use, productivity and commercialization in Uganda maize production. A dissertation submitted to the Directorate of Research and Graduate Training for the award of the degree of Doctor of Philosophy (Economics) of Makerere University, Uganda.

Haruna, V. (2008). Economics of cassava production in Jama'a Local Government Area of Kaduna State: A comparative analysis of local and improved varieties. An unpublished M.sc. thesissubmitted to Department of Agricultural Economics and Rural Sociology, Ahmadu Bello University Zaria.

Holloway, G., Lapar, M., \& Lucila, A. (2007). How big is your neighbourhood? Spatial implications of market participation among Filipino smallholders. Journal of Agricultural Economics, 58(1), 37-60. https://doi.org/10.1111/j.1477-9552.2007.00077.x

Hoppe et al. ( (2001). Structural and finance of characteristics of United States farms, 2001 Family Farm Report, United States Department of Agriculture Economic Research Service. Agriculture Information Bulletin, 3(2), $768-771$.

Horowitz, J., \& Savin, N. (2001). Binary response models: Logits, Probits and Semiparameters. Journal of Economic Perspectives, 15(4), 43-56. http://en.wikipedia.org/wiki/logistic_regression on June 2, 2015

Idiong, I. C. (2007). Estimation of farm level technical efficiency in small-scale rice production in Cross River State, Nigeria: A stochastic frontier approach. World Journal of Agricultural Sciences, 3(5), 653-658.

Idrisa, Y. L., Ogunbameru, B. O., \& Madukwe, M. C. (2012). Logit and Tobit analysis of the determinants of likelihood of adoption and extent of adoption of improved soybean seed in Borno State, Nigeria. Green Journal of Agricultural Sciences, 2(2), 037-045. https://doi.org/10.15580/GJAS.2013.3.1231

Idrisa, Y. L., Shehu, H., \& Ngamdu, M. B. (2012). Effects of adoption of improved maize seed on household food security in Gwoza Local Government Area of Borno State, Nigeria. Global Journal of Science Frontier Research, $12(5), 45-65$.

Iloeje et al. Proceedings of the International Conference on Global Food Crisis: Theme, Global Food Crisis: The Way Forward, Federal. University of Technology Owerri, Nigeria, 387-392.

International Institute of Tropical Agriculture (IITA) (2001). Annual Report on Maize Production. Ibadan, Oyo State. Nigeria.

Jondrow, J. C. A., Lovell, L. S., \& Schmidt, P. (1982). On the estimated of technical inefficiency in the stochastic frontier production function model. Journal of Economics, 19(1), 233-238.

https://doi.org/10.1016/0304-4076(82)90004-5

Joshua, A. (1999). The emerging private seed industries in Nigeria and the way forward in the millennium. Sustainable Maize Production in Nigeria. The challenge in the coming millennium. Valenera, J. A., Falaki, S. M., \& Ado, S. G. eds. Proceedings of the National Maize Production Workshop.July 22-24, Ahmadu Bello University, Zaria.Methodology and Stakeholders Workshop. 108-121. 
Kamara et al. (2006). Participating on-farm evaluation of the performance of the Drought-Tolerant maize varieties in the Guinea Savannahs of Nigeria. Journal of Food, Agriculture and Environment, 4(1), 192-196.

Khawar, J., Zahid, A., \& Farooq, M. (2007). Maize: Cereal with a variety of uses. DAWN Business on 23rd December, 2015. Retrieved from http://wwwdawn.com/2007/03/12/ebr5.html

Koopmans, T. C. (1951). An Analysis of Production, an Efficient Combination Activities, Dans T. C. Koopmans Ed. Activity Analysis of Production and Allocation. Cowles Commission for Research in Economics, Monograph No: 13 Wiley, New York.

Kudi, T. M., Bolaji, M., Akinola, M. O., \& Nasa, I. D. H. (2011). Analysis of adoption of improved maize varieties among farmers in Kwara State, Nigeria. International Journal of Peace and Development Studies, 1(3), 8-12.

Langyintuo, A., \& Mekuria, M. (2005). Modeling Agricultural Technology Adoption Using the Software STATA.CIMMYT-ALP Training Manual No. 1/2005 (Part Two). International Maize and Wheat Improvement Centre, Harare, Zimbabwe.

Lawal, B. O., Saka, J. O., Oyegbami, A., \& Akintayo, I. O. (2005). Adoption and performance assessment of improved maize varieties among smallholder farmers in southwest Nigeria. Journal of Agricultural and Food Information, 6(1), 35-47. https://doi.org/10.1300/J108v06n01_05

Lawal, J. O., \& Oluyole, K. A. (2008).Factors influencing adoption of research results and agricultural technologies among cocoa farming households in Oyo State, Nigeria. International Journal of Sustainable Crop Production, $3(5), 10-12$.

Louwaars, M. P., \& Marrewijk, G. A. M. (1999). Seed supply systems in developing countries. Centre for Tropical Agriculture (CTA).

Matthews-Njoku, E., Ohajianya, D., Nwachukwu, C., Onweremadu, E. U., \& Asiabaka, C. C. (2009). Determinants of adoption of cover cropping technology: an application of multivariate logistic analysis in Imo State, Nigeria.

Michael, G. (1996). Parametric and semi-parametric estimation of the binary response model of labour market participation. Journal of Applied Econometrics, 11(2), 321-339.

Morris, M. L., Tripp, R., \& Dankyi, A. A. (1999). Adoption and impacts of improved maize production technology. A case study of the Ghana grains development project. Economics Program Paper, 13(5), 99-101.

Musaba, E., \& Bwacha, I. (2014).Technical efficiency of small scale maize production in Masaiti District, Zambia.A stochastic frontier approach. Journal of Economics and Sustainable Development, 5(4), 104-111.

National Agricultural Seeds Council (NASC) (2008) Annual Report (2008).

National Seed Service (2000). Assessment of the Seed Market in Nigeria: Structure, functioning, constraints and options.

Nkonya, E., Schroeder, T., \& Norman, D. (1997). Factors affecting the adoption of improved maize seed and fertilizer in northern Tanzania. Journal of Agricultural Economics, 48(1), 1-12. https://doi.org/10.1111/j.1477-9552.1997.tb01126.x

Nsoanya, L. N., \& Nenna, M. G. (2011). Adoption of improved cassava production technologies in Anambra-East Local Government Area of Anambra State Nigeria. Journal of Research in National Development, 9(3), 36-43.

Nwaogu, R. N. (2007). Influence of fertilizer and land prices on short run supply of cassava in Ikwuano L.G.A. of Abia State, Nigeria. African Journal of Agricultural Research, 5(10), 345-367.

Odii, A. C. A. (1998). Modern farm management techniques, Owerri, Nigeria: Alphabet Publishers. 102

Ogunsumi, I. O., Ewuola, S. O., \& Daramola, A. G. (2005). Socio-economic Impact Assessment of maize production technology on farmers' welfare in south west, Nigeria. Journal of Central European Agriculture, 6(1), 15-26.

Ojo, S. O. (2000). Factor productivity in maize production in Ondo state Nigeria. Applied Tropical Agriculture, 15 (1), 57-65.

Oladejo, J. A., \& Adetunji, M. O. (2012). Economic analysis of maize production in Oyo State, Nigeria. Agricultural Science Research Journals, 2(2), 77-83.

Oladele, O. I. (2006). A Tobit analysis of propensity to discontinue adoption of agricultural technology among farmers in Southwestern Nigeria. Journal of Central European Agriculture, 6(3), 249-254.

Olukosi, J. O., Isitor, S. U., \& Ode, M. O. (2006). Introduction to agricultural production economics: Principles and Application. Living Book Series. GU Publications, Abuja, Nigeria, 114-115. 
Omobolanle, L., \& Samuel, O. (2006). Adoption behaviour of farmers in Southwest, Nigeria: The case of soybean farmers. Journal of Central European Agriculture, 6(4), 306-315.

Omolehin, R. A., Adeniji, O. B., Maiangwa, M. G., \& Oguntolu, O. W. (2008). Factors influencing participation of out growers in certified hybrid maize seed production in Giwa Local Government Area of Kaduna State and its policy implication for food security. Journal of Agriculture and Social Research, 8(2), 33-48.

Onu, D. O. (2006). Socio-economic factors influencing farmers' adoption of alley farming technology under intensified agriculture in Imo state, Nigeria. The Philippine Agricultural Scientist, 89(2), 45-52.

Onuk, E. G., Ogara, I. M., Yahaya, H., \& Nannim, N. (2010). Economic analysis of maize production in Mangu Local Government Area of Plateau State, Nigeria. Production, Agriculture and Technology Journal, 6(1), 1-11.

Onyenweaku, C. E., \& Nwaru, J. C. (2005). Application of the stochastic frontier production function to the measurement of technical efficiency in food production in Imo State, Nigeria. Nigeria Agricultural Journal, $10(1), 20-25$.

Oyekale, A. S., \& Idjesa, E. (2009). Adoption of improved maize seeds and production efficiency in Rivers State, Nigeria. Academic Journal of Plant Sciences, 2(1), 44-50.

Oyelade, A. O., \& Anwanane, N. B. (2013). Maize and cowpea production in Nigeria. Advances in Agriculture, Sciences and Engineering Research, 3(11), 1343-1358.

Oyewo, I. O. (2011). Technical efficiency of maize production in Oyo state. Journal of Economics and International Finance, 3(4), 211-216.

Phillip, D. (2001). Evaluation of social gains from maize research in the northern Guinea savanna of Nigeria. In Impact, challenges and prospects of maize research and development in West andCentral Africa. Proceedings of a Regional Maize Workshop, IITA-Cotonou, Benin Republic, 4-7 May 1999, edited by B. Badu-Apraku, M.A.B. Fakorede, M. Ouedraogo, and R Carsky. WECAMAN/IITA, Ibadan, Nigeria, 85

Ruma, S. A. (2008). Challenges of the Nigerian seed industry and the way forward. Proceedings of the workshop for public-private partnership for dynamic seed system in Nigeria and West Africa, Abuja, $8^{\text {th }}-9^{\text {th }}$, October, 2008.

Sadiq, M. S., Yakasai, M. T., Ahmad, M. M., Lapkene, T. Y., \& Abubakar, M. (2013). Profitability and production efficiency of small-scale maize production in Niger State, Nigeria. IOSR Journal of Applied Physics, 3(4), 19-23. https://doi.org/10.9790/4861-0341923

Sall, S., Norman, D., \& Featherstone, A. M. (2000). Quantitative assessment of improved rice variety adoption: The Farmer's perspective. Agricultural Systems, 66(1), 129-144. https://doi.org/10.1016/S0308-521X(00)00040-8

Shobowale, O. J. (1994). Strategies for fulfilling foundation and certified seed requirements evolving Nigerian Seed Development Plan. Adedipe, N. O., I. A. Usman and N. S. Maini eds., Federal Department of Agriculture, Abuja. 121-139.

Simonyan, J. B., Olukosi, J. O., \& Omolehin, R. A. (2010). Socio-economic determinants of farmer's participation in Fadama II project in Kaduna state, Nigeria. Journal of Food and Fibre Production, 1(1), 592-601.

Simonyan, J. B., Umoren, B. D., \& Okoye B. C. (2011). Gender differentials in technical efficiency among maize farmers in EssienUdim local government area, Nigeria. International Journal of Economics and Management Sciences, 1(2), 17-23.

Simtowe, F., Zeller, M., \& Diagne, A. (2009). The impact of credit constraints on the adoption of hybrid maize in Malawi. Journal of Developmental Studies, 30(2), 75-83.

Smith, J., Weber, G., Manyong, V. M., \& Fakorede, M. A. B. (1997). Fostering sustainable increases in maize productivity in Nigeria. In Africa's emerging maize revolution, Lynne Rienner Publishers, London. UK.

Steven, J. F. (1993). Marketing Research Review, Highland Park Incorporation, U.S.A 420pp.

Takeshima, H., \& Yamauchi, F. (2012). Risks and farmers' investment in productive assets in Nigeria. Agricultural Economics, 43(2), 143-153. https://doi.org/10.1111/j.1574-0862.2011.00572.x

Tiri, G. D., Ojoko, E. A., \& Aruwayo, A. (2014). Growth Enhancement Support (GES) Scheme and the challenges of food security in Nigeria.A Review. Asian Research Publishing Journal of Agricultural and Biological Science, 9(7), 76-92.

Tripp, R. (1995). Seed regulatory frameworks and resource poor farmers:A literature review". Network Paper 51. Agricultural Administration Research and Extension, ODI, London. 
Ugwumba, C. O. A., \& Omojola, J. T. (2012). Allocative efficiency and profitability of maize production inputs in Oru East Local Government Area of Imo state, Nigeria. Journal of Agriculture and Veterinary Sciences, 4(1), 46-53.

United Nations Population Fund (UNFPA) (2013). Retrieved from nigeria.unfpa.org/abuja.html on 2nd of August, 2014.

Wikipedia, (2015). Encyclopaedia. Retrieved from http://en.wikipedia.org/wiki/logistic_regression on June 2, 2015

Yusuf, O., Adebayo, C. O., \& Sani, A. (2010). Economic evaluation of improved maize variety production in SabonGari Local Government Area of Kaduna State, Nigeria. In: Baba, K. M., Mohammed U. S., Nmadu J. N (eds) Commercial Agriculture Banking Reform and Economic Downtown: Setting a New Agenda for Agricultural Development in Nigeria. Proceedings of 11 Annual Conference of National Association of Agricultural Economist (NAAE), 30 ${ }^{\text {th }}$ - Nov. 3rd Dec., 2010, pp 121-135.

Yusuf, O., Haruna, V., Yusuf, H. O., \& Ugbabe, O. O. (2008). Factors determining intercropping by small scale melon production in Kogi central Zone of Kogi State, Nigeria. In: Aiyedun, E. A., Idrisa, P. O, Nmadu, J. N (eds). Agricultural Technology and Nigeria's Economic Development. Proceedings of Nigerian Association of Agricultural Economist 7th- 10 $0^{\text {th }}$ October, 2008, held at University of Abuja, Nigeria, pp 120-126.

Yusuf, S. A., \& Malomo, O. (2007). Technical efficiency of poultry egg production in Ogun State.A data envelopment analysis (DEA) approach. International Journal of Poultry Science, 6(1), 622-629. https://doi.org/10.3923/ijps.2007.622.629

Zalkuwi, J. W., Dia, Y. Z., \& Dia, R. Z. (2010). Analysis of economic efficiency of maize production in Ganye Local Government Area Adamawa state, Nigeria. Report and Opinion, 2(7), 1-9.

Zanu, H. K., Antwiwaa, A., \& Agyemang, C. T. (2012). Factors influencing technology adoption among farmers in Ashanti region Ghana. Journal of Agricultural Technology, 8(1), 81-91.

Zellner, A., \& Rossi, P. E. (1984). Bayesian analysis of dichotomous quantitative response models. Journal of Econometrics, 25(1), 365-393. https://doi.org/10.1016/0304-4076(84)90007-1

\section{Copyrights}

Copyright for this article is retained by the author(s), with first publication rights granted to the journal.

This is an open-access article distributed under the terms and conditions of the Creative Commons Attribution license which permits unrestricted use, distribution, and reproduction in any medium, provided the original work is properly cited. 